\title{
Analysis of The Influence of Liquidity, Credit and Operational Risk, in Indonesian Islamic Bank's Financing for The Period 2007-2013
}

\author{
Ousmane Diallo, ${ }^{a *}$ Tettet Fitrijanti, and Nanny Dewi Tanzil ${ }^{b}$ \\ ${ }^{a}$ Cheikh Anta Diop University of Dakar, Senegal \\ bUniversitas Padjadjaran, Bandung, Indonesia
}

\begin{abstract}
The purpose of this paper is to analyze the influence of credit, liquidity and operational risks in six Indonesian's islamic banking financing products namely mudharabah, musyarakah, murabahah, istishna, ijarab and qardh, in order to try to discover whether or not Indonesian islamic banking is based on the "risk-sharing" system. This paper relies on a fixed effect model test based on the panel data analysis method, focusing on the period from 2007 to 2013. The research is an exploratory and descriptive study of all the Indonesian islamic banks that were operating in 2013. The results of this study show that the Islamic banking system in Indonesia truly has banking products based on "risk-sharing." We found out that credit, operational and liquidity risks as a whole, have significant influence on mudarabah, musyarakah, murabahah, istishna, ijarah and qardh based financing. There is a correlation between the credit risk and mudarabah based financing, and no causal relationship between the credit risk and musharaka, murabahah, ijarah, istishna and qardh based financing. There is also correlation between the operational risk and mudarabah and murabahah based financing, and no causal relationship between the operational risk and musharaka, istishna, ijarah and qardh based financing. There is correlation between the liquidity risk and istishna based financing, and no causal relationship between the liquidity risk and musharaka, mudarabah, murabahah, ijarah and qardh based financing. A major implication of this study is the fact that there is no causal relationship between the credit risk and musharakah based financing, which is the mode of financing where the islamic bank shares the risk with its clients, but there is an influence of credit risk toward mudarabah mode financing, a financing mode where the Islamic bank bears all the risk. These findings can lead us to conclude that the Indonesian Islamic banking sector is based on the "risk sharing" system.
\end{abstract}

Abstrak: Penelitian ini bertujuan untuk menganalisis pengaruh risiko kredit, likuiditas dan operasional pada enam produk pembiayaan perbankan syariah di Indonesia yaitu mudharabah, musyarakah, murababah, istishna, ijarah dan qardh, dalam rangka untuk mencoba menjawab pertanyaan apakah atau tidak, perbankan syariah di Indonesia berbasis “risk sharing" sistem. Penelitian ini mengunakan model efek tetap berdasarkan metode analisis data panel, dengan fokus pada periode dari tahun 2007 sampai 2013. Demikian, penelitian ini merupakan penelitian bersifat eksploratif dan deskriptif pada keseluruhan bank syariah Indonesia yang beroperasi saat ini di tahun 2013. Hasil dari penelitian ini menunjukkan bahwa, sistem perbankan syariah di Indonesia dapat dinyatakan memiliki produk perbankan berbasis "pembagian risiko." Kami menemukan bahwa risiko kredit, operasional dan likuiditas secara keseluruhan, memiliki pengaruh yang signifikan terhadap pembiayaan mudarabah, musyarakah, murabahah, istishna, ijarah dan qardh. Ada korelasi antara risiko kredit dan pembiayaan mudarabah, dan tidak ada korelasi antara kredit risiko dan pembiayaan musyarakah,

* Corresponding author's e-mail: ousoubebe@gmail.com

ISSN: $1141-1128$

http://journal.ugm.ac.id/gamaijb 
murabahah, ijarah, istishna dan qardh. Ada pun korelasi antara risiko operasional dan pembiayaan mudarabah dan murabahah, dan tidak ada korelasi antara risiko operasional dan pembiayaan musyarakah, istishna, ijarah dan qardh. Ada korelasi antara risiko likuiditas dan pembiayaan istishna, dan tidak ada korelasi antara risiko likuiditas dan pembiayaan musyarakah, mudarabah, murabahah, ijarah dan qardh. Implikasi utama dari penelitian ini adalah kenyataan bahwa tidak ada hubungan risiko kredit dan pembiayaan berdasarkan musharakah, yang merupakan modus pembiayaan dimana bank syariah berbagi risiko dengan klien, tetapi ada pengaruh risiko kredit dengan pembiayaan mudharabah, modus pembiayaan dimana bank syariah menanggung semua risiko. Temuan ini dapat mengakibabkan kesimpulan bahwa sektor perbankan syariah di Indonesia berdasarkan pada "risk sharing" sistem.

Keywords: ijarab; islamic banking and finance; istishna; mudarabab; musharakab; murabahah; Qardh; risk sharing

JEL classification: M49,P40, Z12

\section{Introduction}

Islamic banking and finance is developing at a remarkable pace even in some nonMuslim countries. This banking and finance concept is based on the Qur'an and the Suna, the Muslim's holy books. For most of the people the prohibition of interest or riba, is the well-known part of islamic financing. For islamic scholars, islamic banking and finance are also known as a profit and loss sharing and risk sharing method of financing. Depositors/savers do not bear any risk in conventional financing; however islamic finance has another solution which is called PLS (profitloss sharing). Risks and profits between the parties involved in any financial transaction are shared by both the financial institutions and depositors/savers in a predefined ratio.

Among all the religions, Islam is the one that claims to have economic laws, as well as a financial system. An islamic financial system is one that complies with islamic religious law (the shariab). Islamic finance has become an important part of the international financial system and was, certainly, one of its fastest growing components over the last few decades. In the wake of the financial crisis, there has been a renewed debate on the role that Islamic financing can play in the stabilization of the global financial system, one related to the strong ethical principles on which this type of financing is based. Nowadays, islamic financing is practiced in USA as well as in Europe and Asia, and in Africa there is also some islamic banks that have developed since the 1990s; islamic finance has developed significantly over the years to become a noticeable part of the international financial system. The value of islamic financial assets worldwide increased from USD 150 billion in the mid-1990s to an estimated USD 1.6 trillion by the end of 2012. Islamic banking continues to dominate the global islamic finance industry, covering approximately 80 percent of total islamic financial assets. Five prominent Gulf States (Iran, Saudi Arabia, the United Arab Emirates, Kuwait and Qatar), as well as countries in South-East Asia (most notably Malaysia) account for most of the Islamic banking market.

While islamic financial instruments share some of the same merits as conventional ones, they have certain distinct features 
that differentiate them from their counterparts. Highlighting the issue of risk, the risks associated with islamic finance and those faced in the conventional financial system are slightly different.

\section{Literature Review}

In any economic model, although perfect risk sharing is not supported by data, it remains important to quantify the operative channels through which (partial) risk sharing takes place. In particular, there is a need to first identify the specific channels through which risk is shared and then quantify the extent of the risk shared through each channel. In economics, this had not been possible until the mold-breaking work of Asdrubali et al. (1996) that proposed a method to quantify the relative contributions of risk sharing channels in the US. Extending the framework of Asdrubali et al. (1996) in a cross-country context, Sorensen and Yosha (1998) empirically explored the risk sharing patterns among the European Union (EU) and OECD countries. Their method built on decomposing the cross-sectional variance of Gross Domestic Product (GDP) into various components, representing the incremental amount of smoothing achieved through factor income flows, capital depreciation, international transfers and savings. This decomposition approach was simply based on standard national account identities: Gross National Income $(\mathrm{GNI})=$ Gross Domestic Product $(\mathrm{GDP})+$ net factor income, National Income $(\mathrm{NI})=$ Gross National Income (GNI) - capital depreciation, Disposable National Income $(\mathrm{DNI})=$ National Income $(\mathrm{NI})+$ interna tional transfers, and, Consumption $(\mathrm{C})=$ Disposable National Income (DNI) - savings.

In islamic finance, the risk sharing percentage in relation to the capital participation is expressed through the Islamic term "alghorm bil ghonm" which means "No reward without risk." Specific channels through which risk is shared have already been identified, now the research can be concentrated on determining the risk level shared through each channel.

\section{Islamic Banking Concept}

The primary sources of the Islamic religious law, the shariah are the Qur'an and the Sunna, the sayings and actions of the Prophet Muhammad transmitted orally in the form of the Hadeeth (the stories of the Prophet's companions). The Qur'an and the Sunna leave room for interpretation: They do not cover all of the questions confronting the contemporary Muslim community ${ }^{1}$ accordingly there is a need to resort to secondary sources of law.

These secondary sources are Islamic jurisprudence (fiqh), based on the interpretations (ijtibad) of experts in particular cases, on deductive reasoning (qiyas) ${ }^{2}$ and on the expert consensus of various schools of thought (ijma). ${ }^{3}$ However, there is controversy

\footnotetext{
${ }^{1}$ The revealed legal evidence is divided into two categories: qat'iyyat (unambiguous evidence) and zanniyyat (probabilistic evidence), whereby the former is not permitted to be interpreted and the latter leaves some scope for interpretation by qualified Muslim jurists.

${ }^{2}$ This means that if a ruling is required on a case not covered by the Quran and the Sunna, a comparison can be made with a similar situation covered by these.

${ }^{3}$ The underlying idea is that the ummah (Muslim community) itself becomes a source of law. However, there is no agreement on the consensus; the scope of which varies from the entire community of believers to the agreements of scholars.
} 
as to whether interpretation is still possible, as some scholars maintain that all interpretation was completed centuries ago. This is further complicated by the divide between the Sunni and the Shia branches of Islam, and the presence of several schools of thought on Islamic jurisprudence within each of these denominations. Orthodox Sunni Islam, for example, has four main schools of law. ${ }^{4}$

Differences in the interpretation of the law (fiqh) can have significant implications for the development of islamic finance. The lack of harmonization of islamic rules, with different scholars expressing different views, could give rise to uncertainty on one critical issue, namely whether certain financial instruments are compliant with the shariah.

Every aspect of Muslim's daily life is regulating by these 4 sources. The Qur'an contains explicit rules regulating personal status, contracts, property, civil and criminal law, and the economic system. The main prescriptions relating to financial transactions are: The prohibition of riba' 5 (i.e. the payment of a fixed or determinable interest on funds); and the prohibition of economic practices that involve the concept of gharar (deceptive uncertainty), maysir (speculation) and haram (prohibited behavior).

\section{Key Prohibitions}

\section{The Prohibition of Riba}

In the Qur'an, there are several verses that condemn riba,' which literally means "Increase, addition and surplus." These originate from a pre-islamic practice whereby the amount due was doubled if the debtor proved unable to repay the debt at maturity. ${ }^{5}$

\section{The Prohibition of Gharar and Maysir}

All activities that contain elements of uncertainty, such as commercial transactions in which there is uncertainty about an asset or its price, are covered by the prohibition of gharar (uncertainty) and maysir (gambling) stipulated in the Qur'an .

Because an element of uncertainty can be found in almost all commercial transactions, it is excessive gharar that is prohibited. For example, excessive gharar can be identified in the case of insurance contracts. Futures, forwards and other derivatives also fall under gharar, as there is no certainty that the object of the sale will exist at the time the trade has to be executed.

These instruments are also subject to the prohibition on maysir, which condemns the speculative exploitation of legal uncertainty in order to draw an unjustified (because it is unfair) advantage. In addition, speculation (maysir) is seen as diverting resources from productive activities.

Gharar and maysir render a contract null and void. However, there can be some exceptions to this general principle. Given the important role of derivatives in the management and allocation of risk and in financial innovation, some islamic economists are making an effort to structure shariah-compliant financial contracts that are similar to derivatives. They argue that some islamic contracts (e.g. salam and istishna' contracts) have certain features in common with derivatives (e.g. futures or forward contracts).

For insurance products, islamic jurists have developed a shariah-compliant system based on mutual cooperation and assistance

\footnotetext{
${ }^{4}$ These are the Hanafi, Maliki, Shafi'i and Hanbali schools of law. For Shi'ites, the Jafari school of law is the largest

${ }^{5}$ In particular, the prohibition is based on different verses in which riba' is contrasted with alms to the poor.
} one. 
(commonly known as takaful). They aim to create a structure very similar to that of conventional mutual insurance. 15 Participants in the takafulpay a sum of money (tabarru') to a mutual cooperative fund, which is then used for compensation should this be necessary. The takaful company acts as the manager of the fund; there is an agency contract and remuneration is seen as a share in any surplus this being the difference between the takaful fund and any payments made. Funds are usually invested on the basis of shariah-compliant contracts, particularly those featuring mudarabah.

\section{The Prohibition of Haram}

Prohibitions under the Qur'an also include haram (forbidden) activities, which are primarily related to tobacco, pornography, arms, alcohol, pork and gambling.

\section{The Profit and Loss Sharing Concept}

The underlying theory of risk sharing suggests that under complete financial markets, the consumption of individuals with identical preferences should not respond to idiosyncratic output shocks but should strongly commove with aggregate consumption (Diamond 1967; Wilson 1968; Cochrane 1991; and Mace 1991). By the same analogy, the standard open macroeconomic models (Obstfeld and Rogoff 1996; Lewis 1996) showed that in the presence of the trade in goods and financial assets, a country's consumption should be less correlated with domestic output, but highly correlated with world consumption. These models predict that in a perfect risk sharing scenario (the complete markets model), a country should be able to completely detach consumption from domestic output fluctuations. To validate these theoretical predictions, there is abundant empirical literature that has exam- ined the perfect risk sharing conjecture (e.g., Obstfeld 1994; Stockman and Tesar 1995; Baxter and Crucini 1995; Lewis 1996). The consensus from this vast amount of literature indicates that there is only a weak presence of risk sharing among countries, which is far from perfect and not consistent with the predictions of standard theory (Kose et al. 2007; Islamaj 2012). The leading explanations offered for this low level of risk sharing include the presence of non-traded goods, incomplete financial markets and high transactions costs.

In the Qur'an, many verses explicitly condemn interest and interest-based transactions. Likewise, many sayings of the Prophet severely condemn interest-based dealings. For instance, Verse 2:275 states that "They say that indeed al-bay' [trade] is like al-riba [interest-based debt contract]. But Allah has permitted al-bay' and has forbidden al-riba." This verse may be considered the cornerstone of the Qur'an's conception of an economy, since from this verse flows major implications of how an economy should be organized. Islamic finance precludes any form of interest-based debt. A creditor cannot make interest-based loans. A creditor has to invest his money directly and bear the risk of his enterprise. He is the direct owner of the assets of his enterprise. A borrower cannot generate wealth on the basis of borrowed money. He cannot contract interest-based debt and use it either for consumption or investment. In islamic finance, the borrower-creditor conflict is absent. Entrepreneurs individually or jointly participate directly in an enterprise with their material and human wealth and share the risk of their enterprise. We define this form of organization as risk taking and risk sharing (Askari et al. 2012). In a loan contract, the creditor assumes no enterprise risk; the latter is borne by the borrower. If 
the investment fails, the borrower is still legally bound to reimburse the loan. In fact, in the Qur'an the repayment of debt is an overriding obligation. No wealth can be inherited prior to the discharge of every debt.

If we examine some of the major crises in the international financial system like the one in East Asia, the instability in the foreign exchange markets, the collapse of the Long-Term Capital Management (LTCM) hedge fund, and the prevailing crisis in the U.S. financial system, we find that the easy availability of credit and the resultant steep rise in debt, particularly short-term debt, are the results of inadequate market discipline in the financial markets due to the absence of risk sharing. (Chapra 2007: 166-173).

Advocates of islamic banking thus argue that islamic banks are theoretically better poised than conventional banks to absorb external shocks because the banks' financing losses are partially absorbed by the depositors (Khan and Bhatti 2008; and Iqbal 1998). Similarly, the risk sharing feature of the PLS paradigm, in theory, allows Islamic banks to lend on a longer-term basis to projects with higher risk-return profits and, thus, to promote economic growth (Chapra 1992; and Mills and Presley 1999).

In investment, risk-sharing means that investors are seeking profits with the expectation that losses can happen. Based on the legal maxim "profit is accompanied with risk" (al-ghorm bil ghonm), risk-sharing in the trading environment is also known as risk-taking (Steffensen 2013).

Under risk sharing, the borrower and lender should share the risk. In banking, the borrower unjustly bears all the risk associated with the investment and vouchsafes the lender a fixed interest income. Shifting the risk to third parties benefits the individual firms but has catastrophic consequences on the entire financial market, just as savings may have negative macroeconomic upshots (as opposed to spending) on output and employment, but ironically, the same savings are beneficial to the individual. However, when the incomeearning asset is the subject matter of the sale contract at a fixed price, there is room for Islamic banks to shift the risk to the client. This risk shifting, as a component of the overall risk management strategy in Islamic finance, is a win-win strategy as opposed to a win-lose strategy in banking (Seif 2009).

\section{History of Islamic Banks in Indonesia}

Islamic finance in Indonesia, the world's largest Muslim country, has evolved since around 1990, mainly in response to the political demands from Muslim scholars and organizations. The history of islamic banks in Indonesia can be traced back to that year of 1990, when the conference of the Majelis Ulama Indonesia (Indonesian Jurist Council) was held in Cisarua, West Java, Indonesia. The first islamic cooperatives were established in 1990, followed by rural banks in 1991 and the first islamic commercial bank in 1992. In 1998, Bank Indonesia gave official recognition, as part of a new banking act, to the existence of a dual banking system, conventional and islamic, or sharia based. This led to the establishment of a second Islamic Commercial Bank (ICB) and, until December 2003, of eight Islamic Commercial Banking Units (ICBU) (out of a total of 138 commercial banks, comprising a total of 299 banking offices), with a continuing upward trend, reaching 3 ICBs and 22 ICBUs, as of December 2006, to actually reach 11 ICBs in 2013 as shown in the Table 1.

The market leaders in islamic finance in Indonesia are the commercial banks. During the reporting period, 1991--2013, they 
Table 1. Islamic Banking Network Islamic Banking Network

\begin{tabular}{lrrrrrrr}
\hline & \multicolumn{7}{c}{ Islamic Banking Network } \\
\cline { 2 - 8 } & $\mathbf{2 0 0 7}$ & $\mathbf{2 0 0 8}$ & $\mathbf{2 0 0 9}$ & $\mathbf{2 0 1 0}$ & $\mathbf{2 0 1 1}$ & $\mathbf{2 0 1 2}$ & $\mathbf{2 0 1 3}$ \\
\hline Islamic Commercial Bank & & & & & & & \\
$\quad$ Number of Banks & 3 & 5 & 6 & 11 & 11 & 11 & 11 \\
$\quad$ Number of Offices & 401 & 581 & 711 & 1215 & 1401 & 1745 & 1870 \\
Islamic Rural Bank & & & & & & & \\
$\quad$ Number of Banks & 114 & 131 & 138 & 150 & 155 & 158 & 159 \\
$\quad$ Number of Offices & 185 & 202 & 225 & 286 & 364 & 401 & 399 \\
\hline
\end{tabular}

Source: Islamic Banks Report, Indonesia Bank 2013 Report

focused on medium and large-scale finance. We are now observing the beginnings of a slow expansion into microfinance. Since Bank Indonesia gave official recognition in 1998 to a dual banking system, conventional and islamic, interest in islamic meso- and macrofinance has spread among the commercial banks, inspired by religious concerns and fuelled by low rates of non-performing loans.

A clearer regulatory acknowledgment of the existence of the Islamic banks in the Indonesian banking system was first mentioned in the Banking Act No. 10/1998 as an amendment to the Banking Act No. 7/1992. In the new banking act, it was stated that commercial banks in Indonesia could operate in the conventional way (based on the interest rate system) or based on shariah principles. It is also important to note that the new regulation allowed a conventional bank to open a shariah branch office with the aim of boosting the development of the industry. Furthermore, after the establishment of the new Central Bank Act No. 23/1999, the importance of the islamic banking industry was strengthened. Under this regulation, Bank Indonesia as the central bank was mandated to regulate, supervise and develop the islamic banks.
Another important milestone in the development of the islamic banking industry in Indonesia took place in 2002 when Bank Indonesia launched the "Blueprint of Islamic Banking Development in Indonesia." The blueprint contained the vision, mission, and strategic objectives to be achieved by islamic banks in the country. Among others, the Islamic banking industry in Indonesia was targeted to capture 5 percent of the total market share of the banking industry by year 2009. Further, just recently, the government issued the Islamic Banking Act No.21/2008 that provided a legal basis for further development of the industry in Indonesia.

\section{The Main Financial Instruments}

The Islamic finance industry has developed a wide range of shariah-compliant financial products. To ensure that they meet this specification, they make use of contracts acceptable under traditional Islamic legal doctrine and also adapt conventional financial contracts so that they comply with the tenets of the shariah. They are mainly financial instruments that emphasize risk sharing and promote entrepreneurship. These instruments are categorized into 3 main groups, gratuitous contracts such as heba, waqf and qardh, trad- 
ing contracts such are ijarah, murabahah, salam, istishna and so on, and investment contracts such as mudarabah and musharakah. This paper will analyze the risk influence towards 6 financial instruments, mudarabah, musharakah, murabahah, istishna, ijarah and qardh.

- Mudarabab is defined as a contract between a capital provider and an entrepreneur or a fund manager, whereby the entrepreneur or fund manager can mobilize the funds of the former for its business activities within the shariah guidelines. Profits made are shared between the parties according to a mutually agreed ratio.

- Musharakah is a contract between two parties whereby both parties provide capital and both may be active in managing the venture. Losses are shared on the basis of how much capital has been contributed. Profits are shared in any way the partners decide.

- Murabahah is the sale of goods at a price, which includes a profit margin agreed to by both parties. The purchase and selling price, other costs, and the profit margin must be clearly stated by the seller at the time of the sale agreement.

- Salam contracts are contracts in which the seller undertakes to supply some specific goods to the buyer at a future date at a mutually agreed price fully paid at the time of the contract.

- Istisna contracts are contracts in which the seller undertakes to supply some specific goods to the buyer at a future date at a mutually agreed price and method of payment.

- Ijarah contracts are the selling of benefits or the use of something, or a service, for a fixed price or wage.
- Qardh contracts are loans in which the debtor is only required to repay the amount borrowed.

\section{Islamic Banks Risk Management Regulations}

Based on the PBI (Bank of Indonesia Regulation) 11/25/PBI/2009 dated July the $1^{\text {st }}, 2009$, set by Bank Indonesia; Islamic banks should, as a minimum, apply risk management on four types of risk, namely (a) credit risk; (b) market risk; (c) liquidity risk; (d) Operational Risk.

In addition to the above risks, Islamic banking is expected to overcome other risks, namely: rate of return risk, equity investment risk, shariah noncompliance risk, displaced commercial risk, and inventory risk.

\section{Preview Research}

Idries (2011) has defined that the liquidity risk is the possible loss resulting from the bank's incapability to either meet its responsibilities or to fund increases in assets as they fall due without incurring undesirable costs or losses. Bauer and Ryser (2004) showed banks' hedging decisions against any risk depend on the initial debt ratio, the size of the liquidation costs, regulatory restrictions, the volatility of the risky assets and the spread between the riskless interest rate and the deposit rate. Siddiqui (2008) found that Islamic banks in Pakistan performed better in terms of assets and returns by being forced to improve their risk management by keeping their liquidity within safe limits.

The next study by Ahmed et al. (2011) investigated the liquidity risk management in islamic banks in Pakistan and his findings were positive but insignificant to the relationship of the size of the bank and its network- 
ing capital to net assets with the liquidity risk in Islamic banks. In addition, the return on assets in islamic banks was found to have a positive correlation to the liquidity risk management. While the next study, also by Shahid and Abbas (2012) analyzed liquidity and credit risks and the findings suggested profitability and liquidity management in conventional banking had performed better than Islamic banking. However, for credit risk management and solvency maintenance, the performance of the Islamic banks was better than that of the conventional banking sector.

According to McNeil and Embrechts (2005) credit risk was the change in a portfolio due to the unpredicted shifts in the credit quality of the issuer or trading partner. According to Arunkumar and Kotreshwar (2005) credit risk caused 70 percent of the total risks that banks faced, while the other 30 percent was shared by the markets and operational risks. In addition, Khan (2003) stated that credit risk was a source of instability in the banking system. Abedifaret al. (2013) had investigated the risks and stability in islamic banking over the period from 1999 to 2009. This study's findings showed that in terms of the insolvency risk, small islamic banks appeared to be more stable, and the loan quality of islamic banks was less responsive to domestic interest rates when compared to conventional banks. While the operational risk is the type of risk that can cause direct or indirect losses, they are normally caused by insufficient or unsuccessful internal practices, people, technology or from external events (BCBS 2001: 2). Al-Tamimi and Al-Mazrooei (2007) found that Islamic banks were faced with similar credit risks and operating risks as the other banks, and Ray and Cashman (1999) showed that operational risks would influence decision making in different ways. Marliana et al. (2011) showed operational risks in Islamic banks were significant and became more complicated compared to conventional banking because of the unique contractual features and general legal environment. The next set of studies analyzed the correlation risks and efficiency. Ariffin et al. (2009) surveyed 28 islamic banks in 14 countries by asking the risk management teams of these banks about the risks that islamic banks faced compared to banks in the traditional banking system. Ariffin et al. showed that islamic banks faced the same risks as western banks but used less technically advanced risk measurement techniques than their western counterparts.

According to Srairi (2009), islamic banks usually took on more risk than western banks due to a lack of experience and unfamiliarity with all the financial tools that could assist them. As a result, islamic banks required more capital to manage this level of risk. Giannini (2013) in her research, named the factors that influenced mudharabab financing in Indonesian Islamic banks, and also showed that the independent variables namely FDR, NPF, ROA, CAR, as well as the level of profit sharing, as a whole, had a systematic influence on mudharabah financing. Prastanto (2013) in his research named the factors that influenced murabahab financing by Indonesian islamic banks, and showed that the variables FDR, NPF, DER, QR and ROE significantly influenced the murababah financing.

\section{Methods}

\section{Research Design}

In this section, we describe the fixedeffects panel model and the model selection process with EViews used throughout this study. A quantitative correlational research 
design was chosen for the paper. In a correlational research design, the researchers who are involved in the correlational research do not influence the variables; rather, they gather the data on the existing variables and investigate the relationships between those variables (Creswell 2009). Therefore, this study would be examining the correlations between credit, liquidity and operational risks, and their influences on the Indonesians Islamic banks financing for the period from 2007 to 2013.

\section{Hypotheses}

The hypotheses of the study are as follows:

$H_{1 a}$ : There is a causal relationship between the credit risk and mudarabah based financing in the islamic banking sector in Indonesia.

$H_{2 a}$ : There is a causal relationship between the liquidity risk and mudarabah based financing in the islamic banking sector in Indonesia.

$H_{3}$ : There is a causal relationship between the operational risk and mudarabah based financing in the islamic banking sector in Indonesia.

$H_{4 a}$ : There is a causal relationship between the credit risk and murabahab based financing in the islamic banking sector in Indonesia.

$H_{5 a}$ : There is a causal relationship between the liquidity risk and murabahab based financing in the islamic banking sector in Indonesia.

$H_{6 a}:$ There is a causal relationship between the operational risk and murabahab based financing in the islamic banking sector in Indonesia.

$H_{7}$ : There is a causal relationship between the credit risk and musharakah based financing in the islamic banking sector in Indonesia.
$H_{8 a}:$ There is a causal relationship between the liquidity risk and musharakah based financing in the islamic banking sector in Indonesia.

$H_{9 a}$ : There is a causal relationship between the operational risk and musharakah based financing in the islamic banking sector in Indonesia.

$H_{10}$ : There is a causal relationship between the credit risk and istisna based financing in the islamic banking sector in Indonesia.

$H_{11 a}$ : There is a causal relationship between the liquidity risk and istisna based financing in the islamic banking sector in Indonesia.

$H_{12 a}$ : There is a causal relationship between the operational risk and istisna based financing in the islamic banking sector in Indonesia.

$H_{13 a}$ : There is a causal relationship between the credit risk and ijarah based financing in the islamic banking sector in Indonesia.

$H_{14 a}:$ There is a causal relationship between the liquidity risk and ijarab based financing in the islamic banking sector in Indonesia.

$H_{15 a}$ : There is a causal relationship between the operational risk and ijarah based financing in the islamic banking sector in Indonesia.

$H_{16 a}$ : There is a causal relationship between the credit risk and qardh based financing in the islamic banking sector in Indonesia.

$H_{17 a}$ : There is a causal relationship between the liquidity risk and qardh based financing in the islamic banking sector in Indonesia.

$H_{18 a}$ : There is a causal relationship between the operational risk and qardh based financing in the islamic banking sector in Indonesia. 


\section{Data}

The data that were used for this study were collected from the audited financial statements of Indonesia's 11 Islamic banks that operate in the country, those banks are: PT Bank Syariah Muamalat Indonesia, PT Bank Syariah Mandiri, PT Bank Syariah Mega Indonesia, PT Bank Syariah BRI, PT Bank Syariah Bukopin, PT Bank Panin Syariah, PT Bank Victoria Syariah, PT BCA Syariah, PT Bank Jabar Banten, PT Bank Syariah BNI, and PT Maybank Indonesia Syariah. For credit, liquidity and operational risks, we used the ratio that the banks evaluate themselves based on the Indonesian Central Bank regulations. The risks would be measured as Table 2.

Table 2. Risks

\begin{tabular}{cl}
\hline Variable & \multicolumn{1}{c}{ Representation } \\
\hline Credit & $\begin{array}{l}\text { NPF (Nonperforming } \\
\text { Finance) }\end{array}$ \\
Liquidity & $\begin{array}{l}\text { FDR (Financing to } \\
\text { Deposit Ratio) }\end{array}$ \\
& $\begin{array}{l}\text { BOPO (Operational } \\
\text { Expense to Operational } \\
\text { Revenue) }\end{array}$ \\
\hline
\end{tabular}

The dependent variables, which were the 6 islamic banking products, were obtained directly from the audited financial statements provided by each bank.

\section{Results and Discussion}

The analyzed data were interpreted to answer the research questions. The coefficient of correlation could be used to find the probability that the data supported the null hypotheses and this information could be used to support or reject the null hypotheses at a level of significance of $p \leq 0.05$ to determine whether to reject, or fail to reject, the null hypotheses about the efficiency and risks in Islamic banking systems. The findings are as follows:

There is a causal relationship between: credit risk and mudarabah based financing; operational risk and mudarabah based financing; operational risk and murabahah based financing; and liquidity risk and istishna based financing.

There is no causal relationship between: credit risk and musharaka based financing; credit risk and murabahah based financing; credit risk and ijarah based financing; credit risk and istishna based financing; credit risk and qardh based financing; operational risk and musharaka based financing; operational risk and istishna based financing; operational risk and ijarah based financing; operational risk and qardh based financing; liquidity risk and musharaka based financing; liquidity risk and mudarabah based financing; liquidity risk and murabahab based financing; liquidity risk and ijarah based financing; and liquidity risk and qardh based financing.

\section{Conclusion}

The "risk sharing principle" stipulates that in some financing products, the islamic banks bear all the risks and therefore the contract between the bank and the client, regarding the share of the benefice, is made al-ghorm bil ghonm (the higher the risk, the higher the return). Our findings support the fact that there is no causal relationship between the credit risk and the typical risk sharing prod- 
uct which is the musharaka financing mode, where the bank shares the risk with the client.

The research showed that there was no causal effect between the credit risk and musharakah based financing, but there was indeed a causal effect between the credit risk and Mudharabah based financing. As these two modes of financing are the so called "profit and loss sharing mode." Musharakab is the one that, in terms of risk, involves the financial institution (shahibul maal, here the
Indonesian islamic banks) and the client (mudharib), we found out that no causal relationship was present here. But, on the other hand, in a mudharabah based financing system, where the financial institution bared all the risk by giving the project the necessary capital. The research found out that there was a causal relationship between the islamic based financing and the credit risk. These findings therefore, support the scholars who stipulated that Islamic banking was profit and loss sharing based financing.

\section{References}

Abdullah, M, S. Shahida; A. G. Ismail. 2011. Operational risk in islamic banks: Examination of issues. Qualitative Research in Financial Markets 3 (2): 131-151. Emerald Group Publishing, Limited.

Abedifar, P., P. Molyneux, and A. Tarazi. 2013. Risk in islamic banking. Review of Finance 17 (0) (January).

Ahmed, N., M. F. Akhtar, and M. Usman. 2011. Risk Management Practices and Islamic Banks: An Empirical Investigation from Pakistan. Interdisciplinary Journal of Research in Business 1 (6) (June): 5057.

Al-Tamimi, H. A., and F. M. Al-Mazrooei. 2007. Banks risk management: a comparison study of UAE national and foreign banks. The Journal of Risk Finance 8 (4): 394-409.

Ariffin, N., S. Archer, and R. Karim. 2009. Risks in islamic banks: Evidence from empirical research. Journal of Banking Regulation 10 (2): 153-163.

Arunkumar, R., and G. Kotreshwar. 2005. Risk Management in Commercial Banks: A Case Study of Public and Private Sector Banks. SSRN eLibrary.

Asdrubali, P., Sørensen, B.E., Yosha, O., 1996. Channels of interstate risk sharing: United States 1963-90. Quarterly Journal of Economics 111: 1081-1110.

Askari, H., Z. Iqbal, N. Krichene, and A. Mirakhor. 2012. Risk Sharing in Finance: The IslamicFinance Alternative. Singapore: John Wiley and Sons (Asia) Pte. Ltd.

Bauer, W., and M. Ryser. 2004. Risk management strategies for banks. Journal of Banking and Finance 28: 331-352.

Baxter, M., and M. J. Crucini. 1995. Business cycles and the asset structure of foreign trade. International Economic Review 36: 821-854.

Chapra, M. U. 1992. Islam and the Economic Challenge. Leicester, U.K.: The Islamic Foundation.

Chapra, M. U. 2007. The case against interest: Is it compelling? Thunderbird International Business Review 49 (2) (March/April): 161-186.

Cochrane, J. H., 1991. A simple test of consumption insurance. Journal of Political Economy 99: 957-976. 
Creswell, J. W. 2009. Research Design: Qualitative, Quantitative, and Mixed Methods Approaches (3 ${ }^{\text {rd }}$ ed.). Thousand Oaks, CA: SAGE publications.

Diamond, P., 1967. Cardinal welfare, individualistic ethics, and interpersonal comparison of utility: Comment. The Journal of Political Economy 75: 765-766.

Giannini, N. G. 2013. Faktor yang mempengaruhi pembiayaan mudharabah pada bank umum syariah di Indonesia. Accounting Analysis Journal 2 (1): 96-103

Idris, A. R., F. F. A. H. Asari, N. A. A. Taufik, N. J. Salim, R. Mustaffa, and K. Jusoff,. 2011. Determinants of islamic banking nstitutions' profitability in malaysia. World Applied Sciences Journal 12 (Special Issue on Bolstering Economic Sustainability): 1-7. 2009.

Islamaj, E., 2012. Financial liberalization and consumption smoothing: What have we learned so far? Working Paper, Vassar College. Available at http://irving.vassar.edu/ faculty/ei/survey.pdf.

Jinnah, M. A. 2012. The concept of risk sharing in takaful. In Time to Move to the Next Phase of Islamic Finance: Risk Sharing and its Significance in Islamic Finance.ISRA Bulletin 13 (December): 6-7.

Khan, T. 2003. Credit risk management: A framework for islamic banking. Paper presented at the Islamic Banking: Risk Management, Regulation and Supervision, Jakarta, Indonesia.

Kose, M. A., Prasad, E.S., Terrones M. E., 2007. How does financial globalization affect risk sharing? Patterns and channels. International Monetary Fund Working Paper WP/07/238.

Lewis K., 1996, What can explain the apparent lack of consumption risk sharing? Journal of Political Economy 104 (April): 267-97.

Mace, B. J. 1991. Full insurance in the presence of aggregate uncertainty. Journal of Political Economy 99: 928-956.

McNeil, A. J., R. Frey, and P. Embrechts. 2005. Quantitative Risk Management: Concepts, Techniques and Tools. Princeton: Princeton University Press.

Mills, P. S., and J. R. Presley. 1999. Islamic Finance: Theory and Practice. Basingstoke: Macmillan Press.

Obstfeld, M., 1994. Are industrial-country consumption risks globally diversified? In: Leiderman, L., and A. Razin (Eds.), Capital Mobility: The Impact on Consumption, Investment, and Growth. Cambridge University Press, New York.

Obstfeld, M., and K. Rogoff. 1996. Foundations of International Macroeconomics: 273. MIT Press.

Prastanto. 2013. Faktor yang mempengaruhi pembiayaan murabahah pada bank umum syariah di Indonesia. Accounting Analysis Journal 2 (1).

Ray, D., and E. Cashman. 1999. Operational risks, bidding strategies and information policies in restructured power markets. Decision Support Systems 24 (3-4): 175-182.

Seif, I. T. 2009. The current financial and economic crisis within the markets: An overview. Paper Presented at the Harvard-LSE Workshop on Risk Management (Islamic Economics and Islamic EthicoLegal Perspectives on Current Financial Crisis), London School of Economics, February 26.

Shahid, M. A., and Z. Abbas. 2012. Financial stability of islamic banking in Pakistan: An empirical study. African Journal of Business Management 6 (10): 3706-3714

Siddiqui, A. 2008. Financial contracts, risk and performance of islamic banking. Managerial Finance 34 (10): 680-694. Emerald Group Publishing, Limited.

Srairi, S. 2009. A comparison of the profitability of Islamic and conventional banks: The case of GCC countries. Bankers, Markets and Investors 98, 16-27. 
Steffensen, J. 2013. Islamic finance sources of growth and prospects for global development (An interview with Daud Vicary Abdullah). The National Bureau of Asian Research (November 7).

Sorensen, B. E., and O. Yosha. 1998. International risk sharing and European monetary unification. Journal of International Economics 45: 211-238.

Stockman, A.C., and L. L. Tesar. 1995. Tastes and technology in a two-country model of the business cycle: Explaining international comovements. American Economic Review 85: 168-185.

Wilson, R., 1968. The theory of syndicates. Econometrica 36: 119-132. 


\section{APPENDICES}

Appendix 1. Mudarabah Estimation Model Result

\begin{tabular}{crrrl}
\hline Variable & Coefficient & Std. Error & t-Statistic & Prob. \\
\hline C & 29.15687 & 0.543405 & 53.65586 & 0.0000 \\
NPF? & -0.128009 & 0.049048 & -2.609843 & 0.0135 \\
FDR? & -0.002422 & 0.002383 & -1.016520 & 0.3168 \\
BOPO? & -0.026800 & 0.005985 & -4.477908 & 0.0001 \\
& & & \\
\hline & Weighted Statistics & \\
\hline R-squared & 0.924687 & Mean dependent var & 61.66870 \\
Adjusted R-squared & 0.897300 & S.D. dependent var & 66.51449 \\
S.E. of regression & 0.959256 & Sum squared resid & 30.36570 \\
F-statistic & 33.76409 & Durbin-Watson stat & 1.469847 \\
Prob(F-statistic) & 0.000000 & & \\
\hline
\end{tabular}

Appendix 2. Musharakah Estimation Model Result

\begin{tabular}{ccccc}
\hline Variable & Coefficient & Std. Error & t-Statistic & Prob. \\
\hline C & 26.86434 & 1.133613 & 23.69797 & 0.0000 \\
NPF? & 0.210539 & 0.112129 & 1.877657 & 0.0690 \\
FDR? & 0.000234 & 0.006055 & 0.038702 & 0.9694 \\
BOPO? & -0.002978 & 0.009510 & -0.313205 & 0.7560 \\
& Weighted Statistics & \\
\hline R-squared & 0.842311 & Mean dependent var & 34.47431 \\
Adjusted R-squared & 0.786655 & S.D. dependent var & 16.52842 \\
S.E. of regression & 0.729260 & Sum squared resid & 18.08187 \\
F-statistic & 15.13448 & Durbin-Watson stat & 0.994889 \\
Prob(F-statistic) & 0.000000 & & \\
\hline
\end{tabular}

Appendix 3. Murabahah Estimation Model Result

\begin{tabular}{crrrr}
\hline Variable & Coefficient & Std. Error & t-Statistic & Prob. \\
\hline C & 30.70116 & 0.424798 & 72.27232 & 0.0000 \\
NPF? & 0.137795 & 0.080777 & 1.705870 & 0.0964 \\
FDR? & -0.003490 & 0.001845 & -1.891724 & 0.0664 \\
BOPO? & -0.026134 & 0.002944 & -8.876128 & 0.0000 \\
\hline & Weighted Statistics & \\
\hline R-squared & 0.879396 & Mean dependent var & 37.48851 \\
Adjusted R-squared & 0.837022 & S.D. dependent var & 16.63726 \\
S.E. of regression & 0.656889 & Sum squared resid & 15.96563 \\
F-statistic & 20.75308 & Durbin-Watson stat & 1.338609 \\
Prob(F-statistic) & 0.000000 & & \\
\hline
\end{tabular}


Appendix 4. Istishna Estimation Model Result

\begin{tabular}{ccccc}
\hline Variable & Coefficient & Std. Error & t-Statistic & Prob. \\
\hline C & 21.98815 & 2.033009 & 10.81557 & 0.0000 \\
NPF? & -0.030544 & 0.108771 & -0.280807 & 0.7817 \\
FDR? & -0.007668 & 0.002690 & -2.850212 & 0.0099 \\
BOPO? & 0.035467 & 0.021276 & 1.666973 & 0.1111 \\
\hline \multicolumn{5}{c}{ Weighted Statistics } \\
R-squared & 0.837579 & Mean dependent var & 28.03265 \\
Adjusted R-squared & 0.772610 & S.D. dependent var & 7.764619 \\
S.E. of regression & 0.593217 & Sum squared resid & 7.038132 \\
F-statistic & 12.89206 & Durbin-Watson stat & 1.609227 \\
Prob(F-statistic) & 0.000002 & & \\
\hline
\end{tabular}

Appendix 5. Ijarah Estimation Model Result

\begin{tabular}{crrrc}
\hline Variable & Coefficient & Std. Error & t-Statistic & Prob. \\
\hline C & 24.20054 & 3.909154 & 6.190734 & 0.0000 \\
NPF? & 0.610310 & 0.316496 & 1.928335 & 0.0662 \\
FDR? & 0.002699 & 0.006915 & 0.390280 & 0.6999 \\
BOPO? & -0.013767 & 0.046095 & -0.298665 & 0.7679 \\
\hline \multicolumn{5}{c}{ Weighted Statistics } \\
R-squared & 0.880023 & Mean dependent var & 24.31133 \\
Adjusted R-squared & 0.822643 & S.D. dependent var & 3.430241 \\
S.E. of regression & 1.444603 & Akaike info criterion & 3.839406 \\
Sum squared resid & 47.99818 & Schwarz criterion & 4.372669 \\
Log likelihood & -55.18961 & Hannan-Quinn criter. & 4.023488 \\
F-statistic & 15.33673 & Durbin-Watson stat & 1.562679 \\
Prob(F-statistic) & 0.000000 & & \\
\hline
\end{tabular}

Appendix 6. Qardh Estimation Model Result

\begin{tabular}{crrrr}
\hline Variable & Coefficient & Std. Error & t-Statistic & Prob. \\
\hline C & 23.00143 & 2.331780 & 9.864326 & 0.0000 \\
NPF? & -0.018763 & 0.163769 & -0.114569 & 0.9096 \\
FDR? & 0.001020 & 0.010323 & 0.098805 & 0.9220 \\
BOPO? & 0.023922 & 0.024999 & 0.956925 & 0.3465 \\
\hline \multicolumn{5}{c}{ Weighted Statistics } \\
R-squared & 0.956617 & Mean dependent var & 36.88316 \\
Adjusted R-squared & 0.941657 & S.D. dependent var & 16.29050 \\
S.E. of regression & 1.549117 & Sum squared resid & 69.59315 \\
F-statistic & 63.94581 & Durbin-Watson stat & 1.206690 \\
Prob(F-statistic) & 0.000000 & & \\
\hline
\end{tabular}

